\title{
The Implementation of Class Supervision and Its Positive Impact
}

\author{
Lisliana \\ Madrasah Aliyah Negeri 1 Banyuasin \\ e-mail: lisliana@gmai.com \\ Happy Fitria \\ Universitas PGRI Palembang \\ e-mail: happyfitriamufly@univpgri-palembang.ac.id \\ Rohana \\ Universitas PGRI Palembang \\ e-mail: rohana@univpgri-palembang.ac.id
}

Article History: Received on 25 September 2020, Revised on 30 September 2020,

Published on 04 October 2020

\begin{abstract}
This research provided the implementation of supervision and its impact on teacher's performance in Madrasah Aliyah Negeri 1 Banyuasin. The method used was descriptive qualitative. The results obtained that class supervision was carried out well in a structured or systematic manner. Class supervision is first scheduled, then good planning is arranged in relation to the things needed to carry out supervision, then supervision is carried out in class by involving each element, until finally a report on the implementation of supervision is conducted and there are recommendations for improvement to be followed up. The implementation of classroom supervision has a positive impact on teachers. That supervision is able to provide guidance to planning, implementation and evaluation of learning.
\end{abstract}

Keywords: Supervision, Class, Teacher's Performance, Positive Impact

\section{A. Introduction}

The key element in the education system especially in schools is the teacher. All learning components other than teachers, starting from the curriculum, infrastructure, costs, and so on will not be meaningful if the essence of learning, namely the interaction of teachers with students, is not qualified. This means that teachers have an important position in providing quality education and learning, so it is necessary for a teacher to always improve his quality. This is in line with the opinion of Janawi (2012) that the quality of teachers must be improved continuously, in line with changing demands and times. This statement means that the quality of education can be improved if teachers have standard competencies related to duties and responsibilities.

With regard to improving teacher's quality, it is important for school principals to design activities that can stimulate teacher quality improvement. One of these activities is the implementation of supervision. Supervision is an effort or coaching activity planned to assist teachers and employees of schools or other educational institutions in monitoring and evaluating their work effectively and efficiently. 
Various kinds of efforts or activities that can be carried out related to supervision include class visits, classroom observations, private conversations between supervisors and teachers and systematic assessments. All of these activities are carried out by the principal as a supervisor. The principal is also known as the principal, head teacher, teacher leader and education leader. The principal is a person who occupies the highest position or position in the school organizational structure (Usman, 2019). Having the highest position among teachers, makes the principal required to be able to act as a supervisor. In carrying out that role, there are several factors that influence the success of the supervision activities carried out by the principal, including the community environment where the school is located, the size of the school which is the responsibility of the principal, the level and type of school, the state of the teachers and staff available., the skills and expertise of the principal itself (Purwanto, 2017).

Among the several factors that influence the success of the implementation of the supervision, there is a statement that the successful implementation of supervision depends on the skills and abilities of the principal himself. Therefore, it is necessary for the principal to improve his competence, one of which is the competence of supervision. This is stated in the Regulation of the Minister of Education and Culture of the Republic of Indonesia Number 6 of 2018 that required competencies inherent in a school principal are managerial competence, entrepreneurial development competence, supervisory competence (Ministry of Education and Culture of the Republic of Indonesia, 2018).

The principal's duty as a supervisor is manifested in his ability to formulate and implement learning supervision programs and take advantage of the results. The ability to compile a learning supervision program must be realized in the preparation of a class supervision program, the development of a supervision program for extracurricular activities, and the development of a supervision program for libraries, laboratories and examinations. The ability to carry out a learning supervision program is manifested in the implementation of a clinical supervision program and in a supervising program for extracurricular activities (Ananda, 2018).

Based on the principal's duties as supervisors, it can be seen that the principal needs to design a regular and continuous supervision program. One type of supervision that is in direct contact with the quality of the learning process and teachers is classroom supervision or academic supervision. The implementation of classroom supervision as one of the principal's programs was emphasized in Kadarwati (2016), which showed that the implementation of academic supervision using class visit techniques was the principal's work program. Academic supervision activities include the planning stage, the implementation stage, and the follow-up stage. The technique of implementing academic supervision can be carried out by the principal as the supervisor. Academic supervision with class visit techniques is carried out by the principal to make it easier to obtain data about the actual situation as long as the teacher is involved in the learning process in the classroom. Furthermore, the principal carries out teacher coaching through discussion about the results of observations of classroom visit supervision.

Given the importance of this supervision activity, it is necessary for schools to organize this program on a regular basis. In its implementation, this supervision activity is carried out a maximum of 2 times in one academic year. This activity can be done in the odd semester and even semester. Unfortunately, this supervision activity is often neglected by the teaching 
staff, so that this activity seems a mere formality to complement school administration. In fact, if you look at the function of this supervision, this activity will have an effect on improving teacher performance, so that it affects the quality of learning as measured by the increase in learning outcomes of students. However, there are several schools that care about the importance of this supervision activity. One of them is Madrasah Aliyah Negeri 1 Banyuasin. This madrasah is the only Madrasah Aliyah with state status in Banyuasin Regency.

The results of the pre-observations related to the implementation of classroom supervision at Madrasah Aliyah Negeri 1 Banyuasin found data and facts derived from reports on the results of class supervision for the 2018/2019 school year at Madrasah Aliyah Negeri 1 Banyuasin, it is known that $34 \%$ of teachers have implemented learning strategies in accordance with Curriculum 2013, 20\% of teachers in teaching and learning activities have used active and interesting strategies, $30 \%$ of teachers have understood well the steps of the 2013 Curriculum Scientific approach, and $35 \%$ of teachers are skilled in formulating question indicators in the assessment process.

Another fact that happened at Madrasah Aliyah Negeri 1 Banyuasin, there are still teachers who make Learning Devices at certain times. Learning devices that are made are sometimes not adapted to the abilities of the students being taught. In addition, when conducting a learning evaluation, the teacher takes the questions listed in the textbook without formulating the grid and indicators of the questions being tested. As a result, students prefer to memorize answers in books rather than cultivate their reasoning power to answer questions. This of course affects the achievement of maximum learning outcomes by students.

In addition, from a short interview when we conducted pre-observations on several students at Madrasah Aliyah Negeri 1 Banyuasin, information was obtained that when there is a madrasah principal or senior teacher in the classroom and sitting following the learning process from beginning to end, students feel happy and enthusiastic about carrying out the learning process. Some of these students argued that at that time the subject teacher provided fun learning, different from previous learning. This shows that a teacher will try to create learning when there is a supervisor in the class.

This research was conducted with the aim of providing a description of the implementation of classroom supervision at Madrasah Aliyah Negeri 1 Banyuasin and to provide a description of the impact of the implementation of classroom supervision in terms of teacher performance aspects at Madrasah Aliyah Negeri 1 Banyuasin.

Etymological understanding of supervision according to Muslich (2018) supervision consists of two words, namely super and vision. Super means above, more and vision means see, look, supervise. The meaning contained in this definition, that a supervisor has a position or position more than the person being supervised. His job is to see, observe, or supervise the people who are supervised.

According to Karuru (2017) supervision is assistance in developing learning situations in order to obtain better conditions. Although the ultimate goal is focused on the learning outcomes of students, what is prioritized in supervision is assistance to the teacher. In supervision activities, someone who carries out supervision activities is called a supervisor, and in this study someone who is a supervisor in an educational unit is the principal. 
Etymologically, the principal is the equivalent of the school principal who is in charge of running the principalship or school headship. The term kekepalasekolahan means anything related to the main duties and functions of the school principal. In addition to the title school principal, there are also other names, namely school administrator, school leader, school manager (Ananda, 2018).

In supervision, there are several types of activities, one of which is classroom supervision. Class supervision or learning is part of educational supervision, because the term classroom supervision will refer to the definition of educational supervision which is broader and more comprehensive. Educational supervision is a service to help, encourage, guide and foster teachers to be able to improve their abilities and skills in carrying out learning tasks (Supardi, 2013). This definition is general in nature, but it clearly states that supervision activities will not be separated from the learning process carried out by teachers and students in the classroom.

Another term for classroom or learning supervision is academic supervision. Academic supervision focuses on supervisor observations of academic activities, in the form of learning both inside and outside the classroom (Muslich, 2018). Another opinion was conveyed by Glickman as quoted in Fathurrohman (2015) Academic supervision is a series of activities to help teachers develop their ability to manage the learning process for the achievement of learning goals. Academic supervision is an effort to help teachers develop their abilities to achieve learning goals.

From the description above, the essence of classroom supervision which is part of educational supervision is an activity of the guidance process to improve the teaching and learning situation so that students can learn effectively and efficiently with increasing learning achievement and quality.

One of the important components that must be considered continuously in improving the quality of education is the teacher. Teachers in the context of education have a large and strategic role. This is because teachers are the "front guard" in the process of implementing education (Janawi, 2012). Therefore, before discussing the position of the teacher in the learning process, it is necessary to know that there are several teacher duties that need to be considered in the learning process. Mulyasa (2017) argues that the main duties and functions of teachers are as educators and teachers, as members of society, as leaders, as administrators, and as implementers of learning.

All of these tasks are the responsibility of the teacher to carry out active, innovative, and effective learning. Mulyasa (2017) states that there are at least two things that teachers must pay attention to so that learning can be carried out effectively, namely starting learning and building competence and character. It was also emphasized that shaping the competence and character of students is a core activity of learning, including the delivery of information about the subject matter or standard material.

\section{B. Methods}

This research is located at Madrasah Aliyah Negeri 1 Banyuasin, which is on Jalan KH. Sulaiman, Kelurahan Kedondong Raye Pangkalan Balai, Banyuasin III District, Banyuasin 
Regency. This research was conducted for 6 months. Starting at the stage of submitting the research title until the thesis exam is held, namely February 2020 to August 2020.

A study of research descriptions is presented by Creswell (2012), that research is a process or steps used to collect and analyze information with the aim of increasing our understanding of a topic or problem. At the general level, the study consists of three steps, namely asking questions, collecting data to answer questions and presenting answers to the questions asked.

This type of research is a case study research. This study produces a well-organized and complete picture of the social unit. In addition, this study also investigates many variables and conditions in a small sample. The social unit referred to in this study is the Madrasah Aliyah Negeri 1 Banyuasin education unit, which focuses on classroom supervision variables, including planning, implementation and evaluation.

The design used in the implementation of this research refers more to qualitative descriptive. Research using this design can also be called naturalistic research because the research is carried out in natural conditions (natural setting). This approach views social reality as something holistic, complex, dynamic, full of meaning and with interactive symptoms.

Arikunto (2018) argues that qualitative descriptive research is the implementation of research that occurs naturally in normal situations and emphasizes natural descriptions and natural data collection, so we are required to go directly into the field. This is also stated by Iskandar (2008) and Moleong (2011), that qualitative research adheres to the naturalistic or phenomenological paradigm of what is understood by research subjects such as perceptual behavior, motivation, action, etc., holistically, and by means of description in the form of words and language, in a specific context which is natural and by making use of various scientific methods. For this reason, this study is appropriate to use a qualitative research design because it is in accordance with the characteristics as required.

Data collection in this study can be done directly or indirectly from the data source. As stated by Sugiyono (2017) that research data can be obtained from primary and secondary sources. According to Umar (2013) that primary data is data obtained from the first source either from individuals or individuals such as the results of interviews or the results of filling out a questionnaire that is usually carried out by us. Primary data in this study can be obtained through observation and interview techniques. Because both of these techniques, directly obtain information or data from the object of research. Meanwhile, secondary data according to Indriantoro \& Supomo (2013) secondary data is a source of research data obtained by us indirectly through intermediary media (obtained and recorded by other parties). Secondary data can be obtained using documentation techniques.

The data analysis process in this study was carried out in 2 stages, namely pre-research analysis and analysis during and after the research. These stages can be done by reducing data, presenting data and making conclusions. The data obtained is also tested for its validity.

\section{Results and Discussion}

The research was conducted by us at Madrasah Aliyah Negeri 1 Banyuasin, with prior coordination with several agencies related to the permit to conduct research. After the permit was obtained, we conducted a field research stage. Initially we made direct observations, then 
conducted discussions with several teachers at random to obtain the information needed in the study. Henceforth, we conducted a structured interview with the head of Madrasah Aliyah Negeri 1 Banyuasin as the highest leader in the work unit.

Observation is one of the techniques used by us to obtain accurate information on the focus of research. There are 8 (eight) main points observed by us. First, regarding the availability of supervision implementation schedule documents. Our observations on this aspect have been fulfilled, because the schedule for implementing supervision is already available and is even posted in the principal's office. This is because the implementation of supervision has become an annual or routine work program, so that in each work program, supervision will be found. Therefore, we were convinced that it was true that Madrasah Aliyah Negeri 1 Banyuasin had conducted supervision. However, it is necessary to deepen the information related to the accuracy of the supervision process carried out.

Second, regarding the availability of supervision planning documents. Even in this aspect, we did not have difficulty obtaining the supervision planning document. As described above, Madrasah Aliyah Negeri 1 Banyuasin has carried out routine supervision so that the planning document for the implementation of supervision is available every year. Even though it has become a routine job, it still pays attention to the aspects that are developing in society. The supervision planning document was prepared by a special team formed by the principal.

Third, the availability of supervision implementation documents. In this aspect, we have no difficulty finding the intended documents. This is because every time the supervision is carried out, the relevant or relevant documents have been well documented. These documents are like the attendance list for the implementation of supervision, as well as other supporting documents.

Fourth, the availability of evaluation documents for the implementation of supervision. As a system that has been well prepared, it is also important to have reports related to what has been done. Likewise with classroom supervision carried out at Madrasah Aliyah Negeri 1 Banyuasin, there are reports or evaluations of the implementation of supervision. Although, we found that the subjectivity side of us were still very visible, one of which was through the report, it did not provide any assertiveness, especially regarding persons who needed further guidance. However, at least this document is available at Madrasah Aliyah Negeri 1 Banyuasin.

Fifth, availability of follow-up recommendation documents from the results of the supervision implementation. In this aspect, we are presented with complete documents. Although the contents of these recommendations are not specific, it is a note for us to provide suggestions or recommendations for improvement through this paper.

Sixth, the availability of monitoring documents, evaluation of supervision recommendations. In principle, this document is rarely found because generally the supervision process is sufficient to include the aspect of recommendations for improvement. However, at Madrasah Aliyah Negeri 1 Banyuasin, we found that there were also monitoring documents. This is an indication that the implementation of classroom supervision at Madrasah Aliyah Negeri 1 Banyuasin has really followed the right process. 
Seventh, the availability of complete teacher learning tools as an indication of good performance. In this aspect, it is clearly not something foreign to the teacher, because classroom supervision has been carried out well, it means that the learning tools are of course available properly. Because, one aspect that is supervised is the availability of learning tools. We are increasingly convinced that the process through which Madrasah Aliyah Negeri 1 Banyuasin has been carried out is very well done.

Eighth, the implementation of the supervision stages correctly and continuously. Referring to the previous six points, it is clear that the stages of supervision have been carried out correctly by Madrasah Aliyah Negeri 1 Banyuasin. Although we provide notes, especially on aspects of objectivity that must be optimized. This is because if the supervision is carried out subjectively, the existing errors cannot be obtained accurately which results in the improvement being not so optimal.

There were forty-three questions asked by us to the respondents, namely the principal and the teacher. First, regarding the preparation of the principal in planning curriculum development program activities. This question is asked as an opening, because the process of implementing learning in the classroom will depend on the curriculum used. Regarding the preparation of the school principal, the principal first explained that every activity carried out at Madrasah Aliyah Negeri 1 Banyuasin must be in accordance with the work program that has been prepared. Therefore, it is clear that every year a design regarding curriculum development is made. This is a form of anticipation if the curriculum is adjusted at any time.

Even if the ministry of education does not fundamentally change the curriculum, the curriculum development process is still carried out in accordance with the needs of implementing classroom learning. Furthermore, we confirmed to several teachers related to the principal's statement. That the principal's statement was confirmed and confirmed by several teachers who were interviewed. At the beginning of each semester, the principal first conducts a meeting to discuss the use of the appropriate curriculum in each subject. So, it is clear that in the first question asked by us accurate information is obtained that the principal together with the teachers formulate a systematic curriculum development program plan.

Furthermore, regarding the principal's considerations in designing curriculum development programs. An impressive answer was conveyed by the principal, that the main consideration is the decisions or rules made by the government. Likewise with developments that occur in society, it is an important consideration for school principals to design curriculum development programs. This is because if the program is available, if at any time there is a curriculum change, the conditions that occur will not be so difficult. This is because everyone understands that the curriculum is dynamic in nature, so it requires readiness for changes in both development and changes to the curriculum as a whole.

We also questioned the activities held at Madrasah Aliyah Negeri 1 Banyuasin related to teaching materials, because they had to be adapted to the developed curriculum. It was firmly stated by the principal that at every opportunity, each teacher had a turn to take part in activities organized by the education office and other agencies, especially for the development of competencies and insights related to the material that must be available in teaching materials. The principal's statement was not denied by the teacher, because it is true that every teacher has the opportunity to attend seminars/workshops/dissemination related to teaching materials on a daily basis. Even if they do not participate in outside activities, 
Madrasah Aliyah Negeri 1 Banyuasin also conducts regular discussion activities with the teacher and the principal, discussing the material that must be adjusted in teaching materials if the curriculum conditions are properly adjusted or developed.

Not different from what was expressed by the principal and teachers, related to activities in order to develop learning strategies and learning media. We assume that if the curriculum changes or is developed, it will certainly have an impact on the right media and strategies to use in learning. The principal and teachers agree that to improve the competence of teachers, they are involved in every activity related to optimizing learning. When viewed from the aspect of implementing activities in schools, the principal affirms that every teacher has the same right to acquire new knowledge. If under certain conditions, that the curriculum is changed in a short time based on a government decision, then the teacher immediately follows activities to develop strategies and learning media. If they cannot participate outside of school, the principal will not hesitate to spend more by inviting experts so that the teacher does not have trouble.

Regarding the implementation of classroom supervision, each teacher answers variously because the implementation of supervision is not carried out simultaneously. This happens because of supervisor limitations. However, the implementation of supervision is in accordance with a predetermined schedule, such as supervision carried out in March, each teacher will be supervised in that month, even though the implementation date will continue to be dynamic.

The techniques used by supervisors in carrying out supervision are more dominant using individual or individual techniques. This is done by the supervisor with the consideration that if the supervision is carried out in groups it will not be effective for the type of classroom supervision. It is different with the implementation of academic supervision as a whole, it will be possible to use group support techniques.

Regarding the stages of implementing class supervision, it is carried out according to the schedule determined by the supervisors. First, the supervisor prepares a work schedule as well as being part of the supervision planning arrangement. Henceforth, the supervisor conducts direct field supervision (classroom). Furthermore, the supervisor observes the teacher who is conducting learning in the classroom.

The main assessment in the implementation of classroom supervision is of course related to the implementation of learning. As well as the lesson planning prepared by the teacher, especially its suitability with the implementation of learning in class. Another component is the ability of a teacher to manage the class. Because a teacher must be able to manage his class well, if the teacher does not do good management, it can clearly interfere with the ongoing learning process. Likewise with the evaluation process carried out by the teacher directly, because learning must have an evaluation at the end of the meeting.

In connection with the teacher's performance when classroom supervision is carried out, it is not affected and continues to carry out learning as it should. This was conveyed by the supervisor of Madrasah Aliyah Negeri 1 Banyuasin. Because according to some teachers, the implementation of supervision is a form of accountability for performance. Therefore, do not lie about learning only during the implementation of supervision. This will backfire for the 
teacher himself, if he lies to himself, the impact will also be on himself, one of which is that there is no recommendation for corrections for the mistakes made.

The implementation of classroom supervision at Madrasah Aliyah Negeri 1 Banyuasin can run well, of course, has supporting factors. Some of them are a good working relationship between the teacher and the principal, then the scheduling of supervision that has been mutually agreed upon. That way, everyone does not feel disadvantaged due to the supervision process being carried out.

Likewise, the inhibiting factor of the implementation of classroom supervision at Madrasah Aliyah Negeri 1 Banyuasin, including the subjectivity of supervisors. This becomes an obstacle, because with this characteristic, the assessment or supervision results will tend to be good. Because of this, some teachers suggest being more objective at each stage of the supervision process.

The strategy used by the supervisor or principal of Madrasah Aliyah Negeri 1 Banyuasin in order to minimize obstacles is to invite an external supervisor. Through external supervisors, the assessment process will be more objective, as well as can be used as a learning process for internal supervisors.

The supporting factors that already exist in Madrasah Aliyah Negeri 1 Banyuasin certainly need to be improved. Because through a harmonious working relationship between colleagues, the scheduling is right. These things can be optimized by generating a close sense of kinship between fellow teachers and colleagues at school, so that personal closeness will be better able to support every process that is undertaken.

So far, the results of the classroom supervision carried out by supervisors at Madrasah Aliyah Negeri 1 Banyuasin have been systematically successful. Although some teachers also admit that it needs to be optimized so that the results obtained through the supervision recommendations can be used as a reference in decision making by the leadership. The supervisor explained that providing an assessment of the implementation of classroom supervision was carried out by referring to the standard operating standards that had been compiled and mutually agreed on supervision at Madrasah Aliyah Negeri 1 Banyuasin. Furthermore, supervisors also conduct personal assessments according to their knowledge and insights regarding supervision.

The components used by supervisors in assessing the professional competence of teachers at Madrasah Aliyah Negeri 1 Banyuasin are personality development, mastery of educational foundations, mastery of learning materials, compiling teaching programs, implementing teaching programs, assessing learning outcomes and processes. It was also agreed by the supervised teacher that what has been going on until now this component has become a basic assessment of professional competence.

For components that are the focus of the assessment during supervision, pedagogical competence is the ability to organize classrooms, create a conducive classroom climate, motivate students to be passionate about learning, provide verbal and non-verbal reinforcement, provide clear instructions to students, be responsive class disruption, refreshing the class if the class gets tired. This assessment component is a standard form 
because it has been mutually agreed upon by teachers and supervisors at Madrasah Aliyah Negeri 1 Banyuasin.

Regarding the components of assessment related to social competence, it is flexible to get along with students, peers and the community, being friendly, friendly and warm towards students, colleagues and the community, being sympathetic and empathic and easy to adapt to the social environment. Likewise with the assessment component for personality competence, namely having faith and devotion to God Almighty, understanding the goals of education and learning, understanding oneself (knowing one's weaknesses and strengths), developing oneself, showing exemplary to students, showing democratic attitudes, tolerance, tolerance. taste, honest, fair, responsibility, discipline, polite, wise and creative. These components are the standard components listed in the operational documents for the implementation of supervision at Madrasah Aliyah Negeri 1 Banyuasin. Thus, this will continue to be the focus of the assessment before any adjustments are made.

Regarding the achievement of learning objectives, the teacher who served at Madrasah Aliyah Negeri 1 Banyuasin stated that every learning carried out referred to the learning objectives. Therefore, they believe that the learning objectives have been achieved. Because, in every field of learning material, learning objectives are always listed.

We continue to dig up information as part of the form of confirmation to the supervised teacher. Especially regarding the information conveyed by the principal about teacher professional development. Each teacher gave his opinion that the information was routinely conveyed by the principal to the teacher, especially now that communication media have made the process of disseminating information easier. Therefore, none of the teachers stated that they did not receive information from the principal regarding teacher professional development.

Furthermore, we deepens the communication by asking about the guidance that is applied as a follow-up to the implementation of supervision. Supervised teachers stated that the coaching provided by the principal depends on what is lacking or not optimizing in what field. Because, there are a lot of coaching provided, including if one of the less than optimal competencies is owned by a teacher, then the guidance given is if there is training or something like that which is organized by the official or other, then the teacher concerned will get priority to be sent to participate in activities. the. If it is not possible for it to be carried out by outsiders, then the supervisor will provide intensive guidance to the teacher concerned.

Regarding the impact of supervision on the learning process, most teachers feel that the implementation of classroom supervision does not interfere with the learning process. Because the supervisor does not participate in teaching, but is passive in the classroom. However, there are also teachers who feel uncomfortable if the supervisor is present in the learning process that is taking place. With the reason, that directly supervised learning makes teachers nervous in delivering learning material. The impact is generally stated by teachers, helping to optimize deficiencies that the teacher had not previously identified independently.

In connection with the implementation of supervision, it will help the teacher professional development process. One of the ongoing programs on teacher professional development is 
through the implementation of supervision. This is because supervision will help every teacher to improve and prepare to become a better and more professional teacher.

As a form of teacher professional development, the lesson planning must be well prepared by the teacher. Some teachers stated that in order to prepare a lesson plan, they must first identify the material in the syllabus, and study the effective hours according to the curriculum needs in the subject being taught. There is also another opinion, that the preparation of a learning plan must begin with a study of the syllabus, because learning plans are derived from the syllabus. Basically, every opinion has a strong hold. It's just that it depends on the habits of each teacher.

We again confirm, regarding the role of supervisors in providing guidance related to the preparation of learning plans. Most of the teachers stated that the supervisor was limited to checking and giving suggestions for arranging learning plans in groups so that discussions could be held if there were obstacles for other teachers.

The next question asked by us is about the perceived change. The teachers seem to agree that supervisors have a good impact on the preparation of learning plans. This is because the recommendations given by supervisors are usually in written form, so it is clear that they must be implemented. One of the recommendations is to make learning plans in groups. It is through this group that discussions can run well, and each teacher has the same opportunity to obtain new information related to the preparation of lesson plans.

In connection with the implementation of learning, we questioned the completeness of learning tools. The teachers answered variously, although the substance was the same. For example, it is stated that before learning begins, the teacher must prepare teaching materials that have been neatly arranged, then the use of appropriate strategies or methods in learning with certain materials, as well as learning media and teaching aids for certain subjects that need them.

We continue to deepen the implementation of supervision. Especially when the supervisor is in class. Some teachers state that learning is a little different if there is a supervisor in the class. Especially the differences occur in the behavior of students who tend to be more passive. If it is further identified, this happens because the supervisor participates in the ranks of students who are following the learning. So that students feel there is additional supervision from behind if they react too actively in class.

For this reason, a teacher must be able to read the situation under certain conditions. This was also expressed by several teachers regarding strategies to improve the quality of learning. The teacher stated that there are many strategies that can be taken, one of which is by making the classroom more relaxed with seating arrangements. So, the classroom becomes a space for creativity which means it is not monotonous. This strategy is quite effective in applying, as evidenced by such learning, students will more easily understand a learning material delivered by the teacher. Because such learning principles make the space for creativity in students' brains more developed.

To optimize the implementation of learning, supervisors usually only provide suggestions and input when deemed necessary. Because, the supervisor's actions will appear in the form of 
more in-depth coaching if there is a violation or other thing that is not appropriate for a teacher to carry out learning.

In essence, the corrections given by the supervisor in relation to the implementation of learning are a positive thing for the teacher. This correction makes the teacher more familiar with the ongoing process, and becomes a material for self-reflection so that the achievement of being a teacher can be optimized again. In the implementation of learning, as previously described, certain materials require media or props. Currently, the most frequently used media and props are digital. So, with the help of infocus, the audio-video media and the combination of the two become easier for students to understand. Likewise with props, it is easier to display in the form of an animation that is displayed through infocus.

Associated with the interactions built by the teacher with students when learning takes place, it is stated to be good. Because until now there have been no reports of non-compliance in the form of interactions between teachers and students. Because, the learning process takes place actively and creatively so that interactions can run well. The teacher assesses the affective, psychomotor and cognitive domains of students. The assessment or evaluation carried out is in accordance with the criteria determined in each subject. Because, each subject has certain criteria. Supervisors carry out their duties in coaching the learning evaluation. The form of coaching carried out by supervisors is usually recommended to take part in training or the like regarding learning evaluation; this is done to optimize teacher insights to then also be shared with other teachers.

As a closing question, we confirmed the changes felt by the teacher after receiving guidance from the supervisor. The answer received by us was amazing, that with a supervisor, someone would pay attention to every activity. Thus, it is unlikely that similar errors will occur in the future. For this reason, the teacher agreed to provide an explanation that it would have a very good impact if the supervisor carried out his duties properly in fostering and providing direction to teachers regarding the implementation of their duties. Evidence of the successful implementation of supervision for optimizing teacher performance is the orderly administration of learning completeness. Initially it became a habit to collect the completeness of learning when it was billed by the principal, but now this process does not happen again. Teacher awareness to collect or administer completeness of learning has been carried out before learning activities at the beginning of the semester take place. This was also proven by us through the complete learning tools for each subject taught for the current semester.

Madrasah Aliyah Negeri 1 Banyuasin, in principle, has organized ongoing and structured supervision. The focus of this research is on classroom supervision, which means that it refers to the main mission of learning. Therefore, in the interview guide as one of the data collection techniques we predominantly confirm learning. The purpose of implementing classroom supervision is to improve, enhance and optimize the quality of learning which means that it will improve the academic achievement of students (Khasanah et al, 2019; Murtiningsih et al, 2019).

By paying attention to the principle of carrying out classroom supervision, Madrasah Aliyah Negeri 1 Banyuasin is able to grow into one of the schools with an excellent accreditation predicate "A". The application of the principles of classroom supervision at Madrasah Aliyah Negeri 1 Banyuasin includes supervision of the implementation of learning, appropriate and 
sustainable coaching, fostering teacher professionalism, creating high academic conditions or nuances, being the right place for collaboration and being a space for creativity in thinking and acting.

As described in the interview description and analysis of the interview data obtained, that in the interview there are several questions that focus on the benefits of implementing supervision. As well as being questioned about the impact of classroom supervision on teachers in the learning process. This is a form of confirmation made by us to the teacher in charge. Various responses were received by us, which in essence every teacher stated the positive impact of classroom supervision activities on the learning process. As the results of an interview conducted on one of the teachers (MS), that the implementation of classroom supervision is able to minimize errors that occur in the learning process.

Likewise with the responses to the questions raised by us related to the changes felt by the teacher after receiving guidance from the supervisor, especially in the aspects of learning planning. The teacher's response was very positive, that the existence of supervision made each teacher feel they had a bigger responsibility, because it was not just carrying out learning in class but also had to prepare all aspects for the implementation of the learning. As well as learning tools. Usually, learning devices will be collected at the end of the lesson or at the end of the semester due to accreditation and other needs, but with supervision, the learning devices are collected on time before the learning activities at the beginning of the semester take place. This is certainly an indication that the teacher's performance in the aspect of learning device readiness is getting better and optimal (Zulfakar et al, 2020; Kartini et al, 2020).

The results of this study clearly provide reinforcement of previous research results. Among them is research conducted by Lalupanda (2019), that academic supervision in cycle 1 and cycle 2 showed an increase in scores in the planning and implementation aspects of learning. If compared, it is clear that academic supervision involving all elements also has a good impact on learning. Likewise with supervision that has focused on aspects of the classroom which means learning.

\section{Conclusion}

The implementation of classroom supervision has been carried out well at Madrasah Aliyah Negeri 1 Banyuasin, as evidenced by the stages or procedures carried out in a structured or systematic manner. Class supervision is scheduled first, then a good plan is drawn up related to the things needed in carrying out supervision, then the implementation of classroom supervision by involving every element that exists, until finally a report is prepared on the implementation of supervision and there are recommendations for improvements to be followed up. That way, the implementation of class supervision at Madrasah Aliyah Negeri 1 Banyuasin is declared to have gone well. The implementation of classroom supervision held at Madrasah Aliyah Negeri 1 Banyuasin has a positive impact on teachers. This is in accordance with the teacher's narrative as well as the results of interviews conducted and documentation which shows that the completeness of learning (syllabus, lesson plans, teaching materials, learning media) has been well documented and on time before the implementation of learning at the beginning of the semester takes place. That supervision is able to provide guidance for lesson planning, learning implementation and learning 
Journal of Social Work and Science Education

Volume 1 (2) 2020

E-ISSN: $2723-6919$

evaluation. That is why teachers feel helped by supervision that is organized in a structured and scheduled manner.

\section{E. Acknowledgement}

Thank to the principal of Madrasah Aliyah Negeri 1 Banyuasin, Rector Universitas PGRI Palembang who gave us the support to do this wonderful project. This project was funded independent. We would also like to thank our friends in Educational Management who helped us a lot in finalizing this project within the limited time frame.

\section{References}

Ananda, R. (2018). Pengaruh supervisi dan profesionalisme guru terhadap kinerja guru di SMP Negeri se-Kecamatan Kalidoni Kota Palembang [The effect of teacher supervision and professionalism on teacher performance in SMP Negeri in Kalidoni District, Palembang City]. Thesis: Universitas PGRI Palembang.

Arikunto, S. (2018). Prosedur Penelitian Suatu Pendekatan Praktik [Research Procedure A Practical Approach]. Jakarta: Rineka Cipta.

Creswell, J. W. (2012). Research Design: Qualitative, Quantitative and Mixed Approaches.

Fathurrohman, M. (2015). Sukses Menjadi Pengawas Sekolah Ideal [Success in Becoming an Ideal School Supervisor]. Yogyakarta: Ar-Ruzz Media.

Indriantoro, N., \& Supomo, B. (2013). Metodologi Penelitian Bisnis [Business Research Methodology]. Yogyakarta: BPFE.

Iskandar. (2008). Metodologi Penelitian Pendidikan Dan Sosial [Educational and Social Research Methodology]. Jakarta: Raja Grafindo Persada.

Janawi. (2012). Kompetensi Guru Citra Guru Profesional [Competency of Professional Teacher Image Teacher]. Bandung: Alfabeta.

Kadarwati, A. (2016). Peningkatan Kualitas Pembelajaran Melalui Supervisi Akademik Dengan Teknik Kunjungan Kelas [Improving the Quality of Learning through Academic Supervision with Class Visit Techniques]. Jurnal Studi Sosial, 1(2) http://ejournal.unipma.ac.id/index.php/gulawentah/article/view/1034/0

Kartini, D., Kristiawan, M., \& Fitria, H. (2020). The Influence of Principal's Leadership, Academic Supervision, and Professional Competence toward Teachers' Performance. International Journal of Progressive Sciences and Technologies, Volume 20 Nomor 1, 156-164.

Karuru, P. (2017). Profesi Kependidikan [Educational Profession]. Toraja: UKI Toraja Press.

Khasanah, U., Kristiawan, M., \& Tobari. (2019). The implementation of principal's academic supervision in improving teacher's professionalism in the state primary schoools. 
International Journal of Scientific \& Technology Research, Volume 8 Issues 8, 11071115 .

Kusumawarti, E., \& Ahmad, H. (2018). Implementation of principal supervision in primary school. SHEs: Conference Series 1 (1), 264-270. dapat diunduh di https://jurnal.uns.ac.id/SHES/article/view/23734/18022

Lalupanda, E. M. (2019). Supervisi Akademik Untuk Meningkatkan Mutu Guru [Academic Supervision to Improve Teacher Quality]. Jurnal Akuntabilitas Manajemen Pendidikan, 7(1). https://journal.uny.ac.id/index.php/jamp/article/view/22276

Moleong, L. J. (2011). Metodologi Penelitian Kualitatif [Qualitative Research Methodology]. Bandung: Remaja Rosdakarya.

Mulyasa. (2017). Uji Kompetensi dan Penilaian Kinerja Guru [Teacher Competency Test and Performance Assessment]. Bandung: Remaja Rosdakarya.

Murtiningsih, M., Kristiawan, M., \& Lian, B. (2019). The Correlation Between Supervision of Headmaster and Interpersonal Communication With Work Ethos of the Teacher. European Journal of Education Studies.

Purwanto, M. N. (2017). Administrasi Dan Supervisi Pendidikan [Education Administration and Supervision]. Bandung: Remaja Rosdakarya.

Sugiyono. (2017). Metode Penelitian Kuallitatif, Kuantitatif Dan R\&D [Quantitative Research Methods, Quantitative And R \& D]. Bandung: Alfabeta.

Supardi. (2013). Kinerja Guru [Teacher's Performance]. Jakarta: PT. Raja Grafindo Persada.

Umar, H. (2013). Metode Penelitian Untuk Skripsi Dan Tesis [Research Methods for Thesis]. Jakarta: Rajawali.

Usman, H. (2019). Administrasi Manajemen Dan Kepemimpinan Pendidikan [Management Administration and Educational Leadership]. Jakarta: Bumi Aksara.

Zulfakar, Lian, B., \& Fitria, H. (2020). Implementasi Supervisi Akademik dalam Meningkatkan Kinerja Guru [Implementation of Academic Supervision in Improving Teacher Performance]. Jurnal Manajemen, Kepemimpinan dan Supervisi Pendidikan, 5(2), 230-244. 